УДК 532.529.5, 519.248

PhD Granovskiy E., Smalii V., Korol D.

\title{
SAFETY OF EMERGENCY RELEASES CONTAINING SOLID PHASE
}

The quantitative risk assessment is the most accurate way of risk determination and the basic approach of obtaining valuable information for further risk management. The risk can be determined as a probability of some event with hazardous consequences occurring during time diapason such as one year. There are variable applications of risk assessment in industry and the technology of risk assessment constantly improves because of widely spread using of risk-oriented approach. Regulations in all countries create specific influence for engineering methods integrating safety in the technology systems. However there are various scientific problems in quantitative risk assessment in specific situations during risk studies. Such situation has occurred in flare pipeline system of combined polymer and refining enterprise. Solid particles of polymers as products of polymer synthesis can be contained in emergency releases and can create deposits along the pipeline of flare system which can be the cause of significant declination from design intent and lead to decreasing or even stopping of the flow rate. The blockage of pipeline can lead to depressurization and rupture of apparatuses with dangerous chemicals inside and consequences can vary from economic losses to ecological damage or even people death. In the current study quantitative method of risk assessment of the flare system has been developed, applied and studied. Main focus was on hazards due the deposition of solid polymer particles along the pipeline and following pipeline blockage. The deposition of solid polymer particles has been simulated, design intent declination criteria have been chosen. The probability of design intent declination has been defined using methods of mathematical statistics and probability theory. Advantages, disadvantages and limits of developed quantitative method of risk assessment have been discussed in the study. The results of study showed that the new approach of quantitative risk assessment of pipe transport systems where deposits occurs can be implemented in a fast way and has easy-to-understand algorithm. The output data showed that the expected frequency of emergency releases, concentration and size of solid particles, flow parameters and the time needed to reach the design intent declination during continuous emergency release have great influence on the risk value of design intent declination.

Keywords: quantitative risk assessment, flare system, particle deposition, pipeline blockage, probability

\section{Introduction}

Adhesion of solid phase on the internal surface of pipelines is a common a reason of declination from design intent and of hazardous consequences. Solid particles, hydrocarbon hydrates, crystalized fluid, coagulated oil and paraffin wax moving along the pipe with main flow can create deposits which can decrease flow rate or even stop it, increase pressure in the pipeline and lead to leakage or rupture [1]. According to [2] decreasing of temperature, defects in pipeline, improper separation device installation, increasing of pressure can cause a serious pipeline blockage and explosion accidents can occur. Possible hazards of pipeline blockage could be as follows:

- people death (3 people died during North Sea accidents 1990 - 1993) [3];

- operation progress delay [3];

- economic losses (US \$ 700 million during North Sea accidents 1990 - 1993, each day loss US \$ 10 million during several months of Qatar accidents 2011 - 2013) [3];

- ecological damage, etc.

Emergency releases on flare can also contain a certain amount of solid phase for example if such releases occur on polymer production plants. To decrease the percentage of solid phase in emergency release, separators, industrial cyclones and filters are widely applied. However even after proper installation of such filtering equipment small amount of thin powder can last in emergency release and can cause the deposition in flare system. These facts make impossible total solid phase separation so there is non-zero likelihood of severe consequences due to deposition of solid phase, pipeline blockage, depressurization and rupture of reactors or other vessels. The combination of likelihood and measurable consequences can be called a "risk" and the quantitative risk assessment procedure (as a preferable practice in this case) should be done [4]. In the current study the existing flare system with possible solid particle deposition was analysed and risk assessment method was developed based on the particle deposition model, probability theory, Fault Tree Analysis technology [5 7]. Based on the results of risk assessment, risk management criteria were evaluated and applied [8].

\section{Theoretical study}

\section{Explanation of case study on the principal scheme}

The risks of pipeline blockage of global flare system was investigated, the principal scheme of flare system is depicted on Figure 1. There are 5 reactors (R1 - R5) of conversion ethylene and propylene to polyethylene and polypropylene correspondently. Reactors are equipped by Pressure-Relief Devices and can create emergency releases with solid polymer particle contamination. Separator S-1 provides some degree of purification of emergency release from solid contaminant. After separator S-1 there is some amount of solid phase which remains in the release. Thereby the 
phenomena of solid particle deposition can be observed on the pipeline connecting nodes $3-8$ and risk of design intent declination can occur.

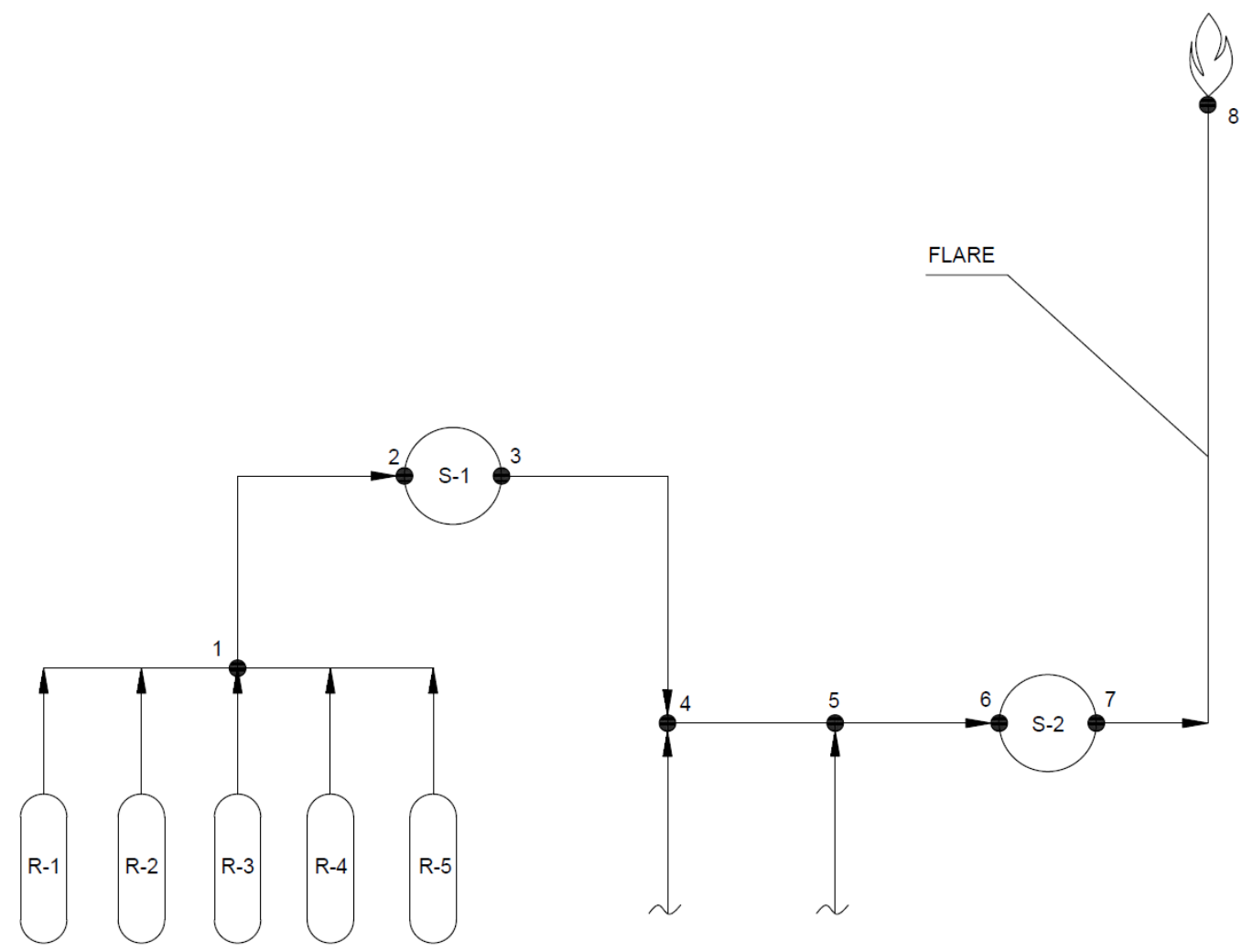

Figure 1. Schematic depiction of case-study flare system with solid particle contamination of emergency releases

There are several other installations which are making the emergency releases in the global flare system and connect to the global flare system in nodes 4 and 5 . We investigate only one pipeline (nodes $3-8$ ) connecting the Separator S-1 and the head of flare. Separator S-2 provides only liquid phase separation and assumed to be a node (6/7) with special resistivity. The resulting pipeline where particle deposition occurs is shown on Figure 2.

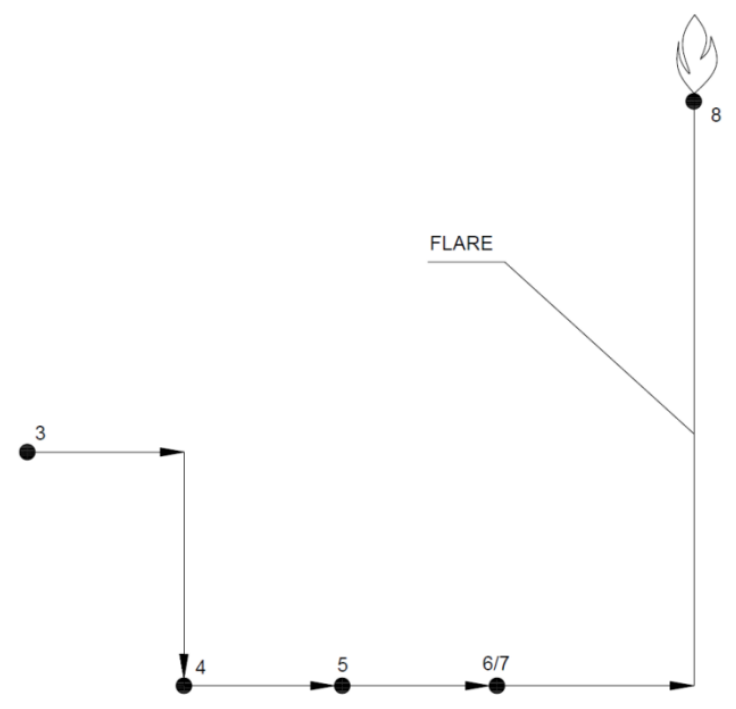

Figure 2. Schematic depiction of pipeline where solid particle deposition occurs during emergency releases

As design intent the flow rate of total emergency release has been chosen. The total emergency release is a sum of emergency releases from reactors R-1 - R-2 and consists of ethylene gas, propylene gas and polymer particles. Thereby the object of study has been defined and method explained below was applied in the way of obtaining the probability of certain declination from design intent during given period of time. 
Objective: to determine the probability of reaching the specific amount of emergency releases per year which lead to declination from design intent of flare system.

Decision-making: based on the obtained risk data, a decision should be made on the possibility of further operation of the pipeline and on the frequency of inspection and cleaning of the inner surface of the pipeline.

Input data:

1) The probability of valve actuation per year;

2) Calculation of valves (relieving pressure, temperature, composition of the emergency release, valve capacity, valve location);

3) The parameters of the apparatus on which the valve is located (temperature, pressure, composition and amount of the mixture stored in it);

4) The duration of the release;

5) Hydraulic calculation of the pipeline;

6) Strength calculation of the pipeline.

The worst release is defined as one of the possible releases at which, for the same simulation time of release and particles deposition, the greatest resistance of the pipeline section with respect to the calibration system is observed.

The calibration system is a gas (air, a mixture of hydrocarbons, etc.), which is closest in its hydrodynamic properties (kinematic viscosity, density, molecular weight) to mixtures in all apparatuses in which the presence of solid impurities is possible. The mixture that is closest to the rest of the mixtures, which exists in one of the devices with its parameters of state, can be taken as the calibration system.

To determine the worst case emergency release, we followed these steps:

1) To carry out a series of numerical experiments for a fixed duration of simulation (e.g. 100 seconds), with release parameters corresponding to the parameters of the state of mixtures in the apparatus; pipeline;

2) At the end of the test, record the distribution of the profile of the thickness of deposits on the walls of the

3) For each obtained profile of the sediment thickness, make a hydraulic calculation for the pipeline in relation to the calibration system;

4) Record the flow rates of the calibration system for different profiles of sediment thickness: the profile of the sediment, which gives the lowest flow rate, refers to the worst release.

In order to determine the time to reach the minimum flow rate of the pipeline (according to design intent), it is necessary to simulate the sedimentation of solids for the worst release.

Let's take the pressure at the inlet to the pipeline equal to the maximum allowable pressure at a given point (node 3 ) in the pipeline. The duration of the release, at which there is a decrease in the flow rate of the pipeline below the calculated-necessary, is the time to reach the declination from design intent.

To determine the likelihood of reaching the minimum allowable flow rate of the pipeline during the year, it is necessary to find out the number $\mathrm{n}_{\mathrm{ave}}$ of releases that must be made in order to reduce the flow rate of the pipeline to the minimum allowable value according to the formula:

$$
\mathrm{n}_{\mathrm{ave}}=\frac{\tau_{\text {lim }}}{\Delta \tau_{\mathrm{ave}}}
$$

where: $\tau_{\text {lim }}-$ time [s] to reach the minimum allowable flow rate in the pipeline for the worst release; $\Delta \tau_{\text {ave }}-$ average duration $[\mathrm{s}]$ of release.

The average emergency release duration can be determined as:

$$
\Delta \tau_{\mathrm{ave}}=\frac{\sum_{\mathrm{i}=1}^{\mathrm{k}} \Delta \tau_{\mathrm{i}}}{\mathrm{k}}
$$

where: $\mathrm{k}$ - the number of apparatuses producing discharges containing solid particles; $\Delta \tau_{\mathrm{i}}-$ duration [s] of release from the i-th apparatus.

Suppose the number of emergency releases is a random variable and appearance of this number can be described by the Poisson distribution law. Let's consider the frequency [year-1] $\lambda_{\Sigma}$ of valve actuation, located on each of the apparatuses, the release of which contains solid particles. Then the probability that there will be no less than $n_{\text {ave }}$ discharges containing solid particles is [6]:

$$
\mathrm{P}\left(\geq \mathrm{n}_{\mathrm{ave}}\right)=1-\sum_{\mathrm{i}=0}^{\mathrm{n}_{\mathrm{ave}}-1} \mathrm{P}(\mathrm{i})
$$

The probability that discharges will occur i times during 1 year is [6]:

$$
P(i)=\frac{a^{i}}{i !} \cdot e^{-a}
$$

where: $\mathrm{a}$ - the mathematical expectation of the number of discharges in 1 year.

Parameter a is calculated as follows [6]:

where: $\tau$ - observation time (1 year).

$$
\mathrm{a}=\lambda_{\Sigma} \cdot \tau
$$

The total emergency release frequency $\lambda_{\Sigma}$ can be defined as:

$$
\lambda_{\Sigma}=\sum_{\mathrm{i}=1}^{\mathrm{N}_{\mathrm{k}}} \lambda_{\mathrm{i}}
$$

where: $\lambda_{i}$ - frequency of emergency release from the $\mathrm{i}$-th valve; $\mathrm{N}_{\mathrm{k}}$ - the number of valves through which mixtures containing solid particles are discharged.

The frequency of valve actuation can be determined if the probability of at least one actuation of the valve per year of observations is known [6]: 
Equation (7) gives:

$$
\mathrm{P}_{\mathrm{i}}(\geq 1)=1-\frac{\left(\lambda_{\mathrm{i}} \cdot \tau\right)^{0}}{0 !} \cdot \mathrm{e}^{-\lambda_{\mathrm{i}} \cdot \tau}=1-\mathrm{e}^{-\lambda_{\mathrm{i}} \cdot \tau}
$$

$$
\ln \left(1-P_{i}(\geq 1)\right)=-\lambda_{i} \cdot \tau \rightarrow \lambda_{i}=-\frac{\ln \left(1-P_{i}(\geq 1)\right)}{\tau}
$$

Thereby, using equations (1) - (8), the probability of reaching the minimum allowable flow rate of the pipeline within 1 year is determined.

\section{Results and discussion}

Analysis of solid particles movement in the flare system showed that the pipeline with possible solid phase deposition starts in the node 3, moves through nodes 4,5,6,7 and finishes in the node 8 (Figure 2).

The pipeline with particle deposition phenomena consists of two parts:

- the first part with length $\sim 150 \mathrm{~m}$, diameter $\sim 200 \mathrm{~mm}$ and connects separator $\mathrm{S}-1$ and joint point 5 (the connection with $1200 \mathrm{~mm}$ diameter pipeline of general flare system);

- the second part with length over $3000 \mathrm{~m}$, diameter $1200 \mathrm{~mm}$ and connects node 5 with flare head 8 (Figure

1).

The deposition of solid particles of polymer was simulated under conditions:

- moving fluid: gas consisting of ethylene and propylene;

- pressure in the node 3: 250000 $\mathrm{Pa}$;

- pressure in the node 8: $101325 \mathrm{~Pa}$;

- the flow is isothermal, the temperature $~ 340 \mathrm{~K}$;

- solid particles composition: polypropylene;

- solid particle size: $125 \mu \mathrm{m}$;

- solid particle concentration: $0.1 \%$ by mass of moving fluid exactly after separator $\mathrm{S}-1$.

As design intent the value $2.658 \mathrm{~kg} / \mathrm{sec}$ of mass flow rate of the maximal emergency release has been chosen. Design intent declination is a decreasing of the flow rate in the pipeline less than $2.658 \mathrm{~kg} / \mathrm{sec}$. The results of numerical simulation showed that the design intent declination was observed approximately at 21500 seconds of simulation time (Figure 3).

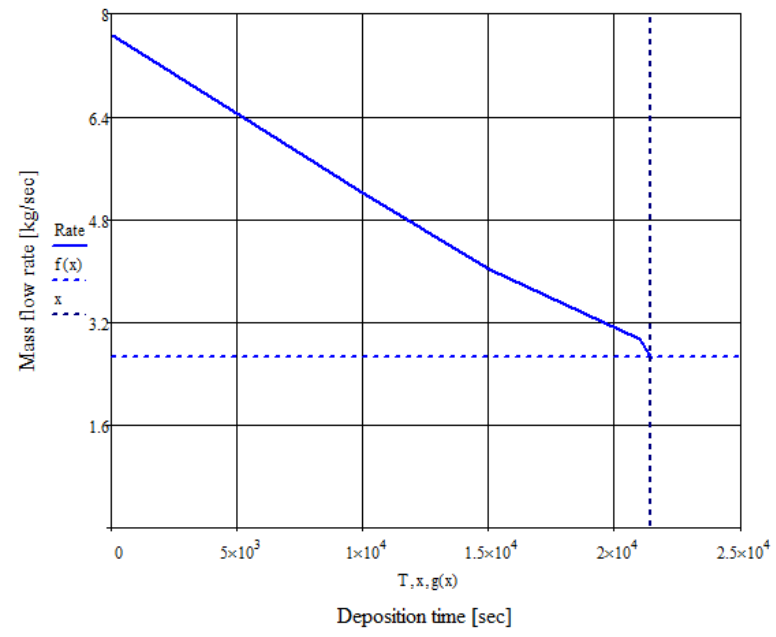

Figure 3. The graph of mass flow rate dependence from time in the pipeline where the process of solid phase deposition occurred

After additional simulation for 60000 seconds, the critical part of pipeline with the largest deposits thickness has been observed starting from separator S-1 until the joint point 5. The deposit thickness was more than $0.09 \mathrm{~m}$ in the point near S-1 at the moment of time 60000 (Figure 4).

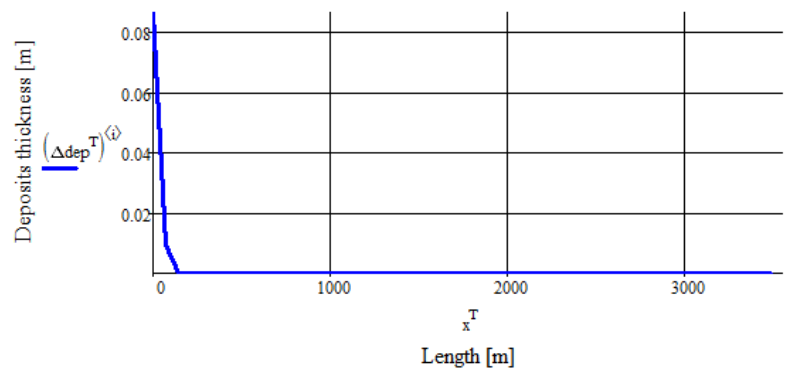

Figure 4. Deposits thickness distribution along the pipe at $60000 \mathrm{sec}$

The diameter of pipe (accounting deposit thickness) was about $0.02 \mathrm{~m}$ at 60000 -th second which corresponds to almost total pipeline blockage. This phenomenon can be explained in terms of deposition model: the deposition rate is related 
to size and concentration of particles, the fluid properties such as temperature, viscosity and density [5]. All mentioned above parameters have their maximum at points which located closer to S-1 and affect the deposition rate making its value the largest in comparison to more far-located relatively to the node 3 points of pipeline.

The closest points relatively to node 3 were analysed and time-dependency of average deposits thickness was obtained and depicted at Figure 5.

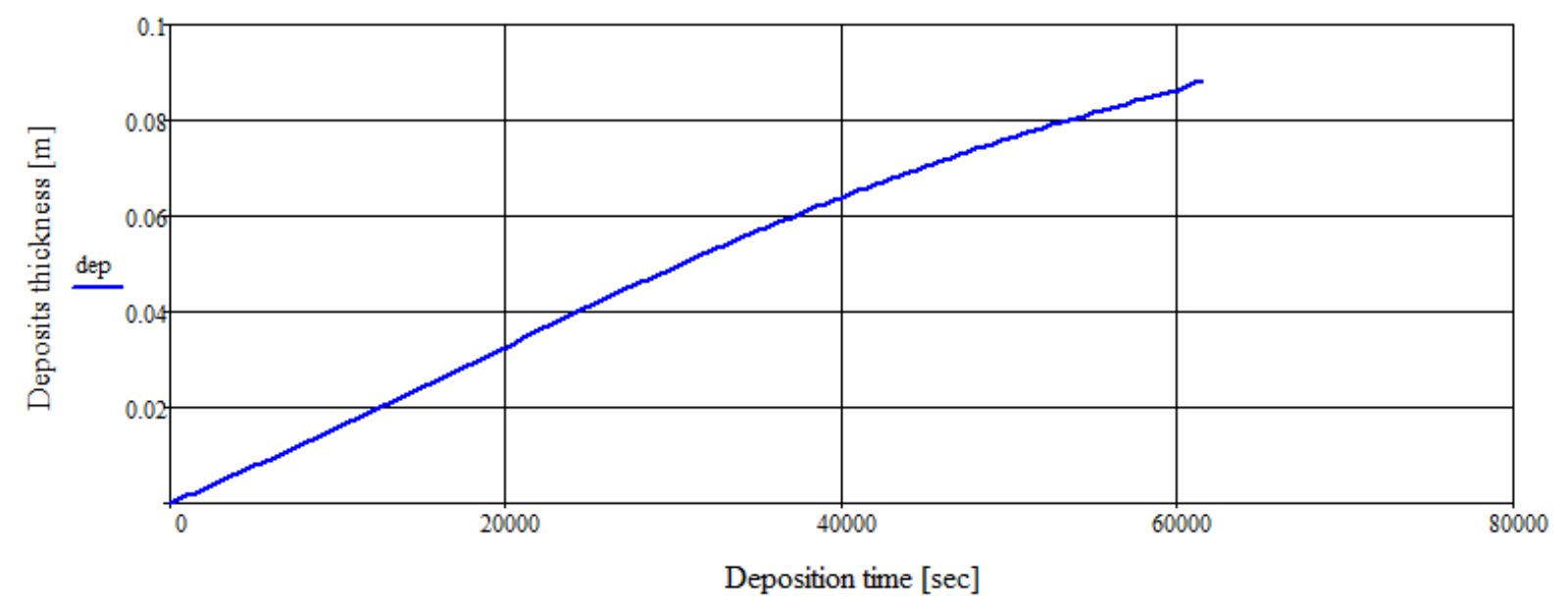

Figure 5. Time-dependency of deposits thickness near the node 3

The monotonous almost linear increasing of the deposits thickness can be observed at Figure 5 though some noticeable decreasing of deposition rate can be seen after 40000 seconds. This phenomenon can be explained by decreasing of the flow rate due the solid phase deposition process.

The probability of specific amount of emergency releases $\mathrm{P}_{\Sigma}(\geq 1)$ which leads to design intent declination was obtained using method of Fault Tree Analysis [7]. The value of probability $\mathrm{P}_{\mathrm{er}}(\geq 1)$ is $6.08 \cdot 10^{-3}$ per year, so the expected amount of the releases $\lambda_{\Sigma}$ during a 1 year is $6.099 \cdot 10^{-3}$ correspondently to equation (8). The average time $\Delta \tau_{\text {ave }}$ of the releases is about 120 seconds. Using equation (1) and considering the time 21500 sec of design intent declination, the amount of the releases $n_{\text {ave }}$ needed to reach the big enough resistivity of pipeline is about 179 times. The probability $\mathrm{P}\left(\geq \mathrm{n}_{\text {ave }}\right)$ of reaching more than 179 emergency releases during a year accounting the expected amount $\lambda_{\Sigma}=6.099 \cdot 10^{-3}$ of releases per year makes the probability of this event less than $10^{-17}$ per year. So the results of risk analysis allows exploitation of the polymer production installation connected to the flare system because of neglected influence on the total individual risk (acceptable value is about $10^{-6}$ per year) of the risk caused by pipeline blockage due to solid particles contamination and deposition [4].

\section{Conclusions}

The developed method of quantitative risk assessment of pipeline systems with possible solid phase contamination has shown applicability to real dangerous object on example of flare system of refinery and polymer enterprise. Obtained data showed that there is no significant probability of pipeline blockage (value of probability $\leq 10^{-17}$ per year) for further exploitation of flare system with possible solid phase contamination after emergency releases from polymer synthesis reactors. The main reason of acceptable risk value is low probability of emergency release due to advanced automation control system. There is significant limitation: if continuous releases with solid phase can occur then the risk is unacceptable because of the time of total blockage during continuous release is about 17 hours. The most critical part of flare system is the pipeline of diameter $200 \mathrm{~mm}$ (nodes $3-5$ ) which is located between separator S-1 and joint point 5 with $1200 \mathrm{~mm}$ diameter pipeline due the high deposition rate of solid particles. The large deposition rate in the critical part compared to the other part of flare system occurs due the next reasons:

- high concentration of solid phase after separator S-1;

- relatively high velocity, turbulence and density of the flow in critical part of pipeline;

- low diameter of critical part (200 mm against $1200 \mathrm{~mm}$ of the diameter of other part of pipeline).

There are some disadvantages of the used particle deposition model [5] which can greatly influence on results or time needed for data preparation:

- not sufficient validation of particle deposition model causes uncertainty in the output data;

- equal length of elementary parts causes difficultness of defining the Darcy coefficient of the elementary parts. The disadvantages of the risk analysis method can be such as using only one probability distribution law (Poisson equation); conservative estimations like the probability of particle sticking to the pipe wall equals 1 (which is less than 1 in reality) etc.

Thereafter new developed approach can be applied for quantitative risk assessment with some limitations and considerations. The method should be refined in both ways: improving the particle deposition model and method of probability estimation of design intent declination and can be used as a base for future risk studies of pipeline blockage in chemical, oil or gas industry.

Acknowledgements. This work was supported by Scientific Centre of Risks Research "RIZIKON". 


\section{References}

1. Blockages detection technology for oil pipeline / E.Liu, S. Peng, H. Zhang, L. Huang. // Journal of the Balkan Tribological Association. - 2016. - p. 1045-1057.

2. Causes of oil \& gas pipeline blockage [Electronic source] // HK Huichuan International Petroleum Equipment CO., LTD. - Site address: https://www.hcpetroleum.hk/wap/news-detail/46.

3. Wang Z. Natural Gas Hydrate Management in Deepwater Gas Well / Z. Wang, B. Sun, Y. Gao., 2020. - 232 p. 4. Rausand M. Risk assessment: theory, methods, and applications / Marvin Rausand. - Hoboken: John Wiley \& Sons, 2011. $-644 \mathrm{c}$.

5. Granovskiy E. Model of Solid Particle Deposition from the Turbulent Gas Flow / E. Granovskiy, V. Smalii. // Naukovi visti Dalivskoho universitetu.

6. E. S. Ventzel, L. A. Ovcharov. Probability theory and its engineering applications. 2nd ed., Erased. - M .: Higher school, 2000. - 480 p.

7. Fault Tree Handbook / W. E.Vesely, F. F. Goldberg, N. H. Roberts, D. F. Haasl. - Washington, D.C.: U.S. Nuclear Regulatory Commission, 1981. - 210 p.

8. $\quad$ ISO 31000 Risk management — Principles and guidelines.

Кількісна оцінка ризику є найбільш точним способом визначення ризику та основним підходом отримання ичінної інформації для подальшого управління ризиками. Ризик можна визначити як імовірність певної подї з небезпечними наслідками, щзо може відбуватися протягом часового періоду, наприклад, одного року. У промисловості існують різні варіанти застосування оцінки ризику, і технологія оцінки ризику постійно вдосконалюється завдяки широкому розповсюдженню використання ризик-орієнтованого підходу. Нормативні акти у всіх краӥнах особливим чином впливають на інженерні методи, що стосуються безпеки технологічних систем. Однак, під час досліджень ризиків, існують різні наукові проблеми кількісної оцінки ризику в конкретних ситуачіях. Така ситуація мала місие у факельній трубопровідній системі комбінованого полімерного та нафтопереробного підприємства. Тверді частинки полімерів як продукти синтезу полімерів можуть міститися в аварійних викидах і можуть створювати відкладення вздовж трубопроводу факельної системи, щцо може бути причиною значного відхилення від иџілей проекту і призвести до зменшення або навіть зупинки витрати потоку. Блокування трубопроводу може призвести до розгерметизачії та розриву апаратів з небезпечними хімічними речовинами всередині, $і$ наслідки можуть варіюватися від економічних втрат до екологічної икоди або навіть загибелі людей. У иьому дослідженні розроблено, застосовано та вивчено кількісний метод оцінки ризику факельної системи. Основна увага була зосереджена на небезпеках, пов 'язаних з осадженням твердих частинок полімеру вздовж трубопроводу та наступним блокування трубопроводу. Було проведено моделювання осадження твердих частинок полімеру, обрано критерії відхилення від цілеей проекту. Імовірність відхилення від иілей проекту визначена за допомогою методів математичної статистики та теорії ймовірностей. У дослідженні обговорювались переваги, недоліки та обмеження розробленого кількісного методу оцінки ризику. Результати дослідження показали, щзо новий підхід кількісної оичнки ризиків систем трубопроводів, де відбуваються відкладення твердої фази, може бути ивидко впроваджений та має легкий для розуміння алгоритм. Вихідні дані показали, щзо очікувана частота аварійних викидів, концентрація і розмір твердих частинок, параметри потоку та час, необхідний для досягнення відхилення проектних намірів під час безперервного аварійного викиду, мають великий вплив на значення ризику відхилення від ияілей проекту.

Ключові слова: кількісна оцінка ризику, система спалаху, осадження частинок, закупорка трубопроводу, ймовірність

Количественная оиенка риска является наиболее точным способом определения риска и основным подходом получения ценной информации для дальнейшего управления рисками. Риск можно определить как вероятность определенного события с опасными последствиями, которое может происходить в течение временного периода, например, одного года. В промышленности существуют различные варианты применения оценки риска, и технология оценки риска постоянно совершенствуется благодаря широкому распространению использования риск-ориентированного подхода. Нормативные акты во всех странах особым образом влияют на инженерные методы, касающиеся безопасности технологических систем. Однако, во время исследований рисков, существуют различные научные проблемы количественной оценки риска в конкретных ситуациях. Такая ситуация имела место в факельной трубопроводной системе комбинированного полимерного и нефтеперерабатывающего предприятия. Твердые частищы полимеров как продукты синтеза полимеров могут содержаться в аварийных выбросах и могут создавать отложения вдоль трубопровода факельной системы, что может быть причиной значительного отклонения от целей проекта и привести к уменьшению или даже остановке расхода потока. Блокировка трубопровода может привести к разгерметизаџии и разрыву аппаратов с опасными химическими веществами внутри, и последствия могут варьироваться от экономических потерь до экологического ущчерба или даже гибели людей. В этом исследовании разработан, применен и изучен количественный метод оценки риска факельной системы. Основное внимание было сосредоточено на опасностях, связанных с осаждением твердых частии полимера вдоль трубопровода и 
последующей блокировкой трубопровода. Было проведено моделирование осаждения твердых частии полимера, избран критерий отклонения от целей проекта. Вероятность отклонения от целей проекта определена с помощью методов математической статистики и теории вероятностей. В исследовании обсуждались преимущества, недостатки и ограничения разработанного количественного метода оченки риска. Результаты исследования показали, что новый подход количественной оченки рисков систем трубопроводов, где происходят отложения твердой фазы, может быть быстро внедрен и имеет легкий для понимания алгоритм. Выходные данные показали, что ожидаемая частота аварийных выбросов, концентрация и размер твердых частиц, параметры потока и время, необходимое для достижения отклонения проектных намерений во время непрерывного аварийного выброса, имеют большое влияние на значение риска отклонения от иелей проекта.

Ключевые слова: количественная оценка риска, факельная система, осаждение частии, засорение трубопровода, вероятность.

Грановський Е. О., к.т.н., генеральний директор, ТОВ Науковий центр вивчення ризиків «Різікон»

Смалій В. В., технічний директор, ТОВ Науковий центр вивчення ризиків «Різікон», Східноукраїнський національний університет імені Володимира Даля, jarkfiz@gmail.com

Король Д. Р., завідуючий відділу промислової безпеки, ТОВ Науковий центр вивчення ризиків «Різікон», Східноукраїнський національний університет імені Володимира Даля

Granovskiy E., PhD, director general, Scientific Center of Risk Investigations "RIZIKON"

Smalii V., chief technical officer, Scientific Center of Risk Investigations "RIZIKON", Volodymyr Dahl EastUkrainian National University, jarkfiz@gmail.com

Korol D., chief of the department of process safety, Scientific Center of Risk Investigations "RIZIKON", Volodymyr Dahl East-Ukrainian National University 